\title{
Review
}

\section{Glucagon-like peptide-1, a new hormone of the entero-insular axis}

\author{
C. Ørskov \\ Department of Clinical Chemistry, Rigshospitalet, University of Copenhagen, Copenhagen, Denmark
}

\begin{abstract}
Summary. The post-translational processing of proglucagon in the small intestine gives rise to glucagon-like peptide-1 (PG 78-107 amide) which has profound effects on the endocrine pancreas, and in many species also on the stomach. Glucagon-like peptide-1 (PG 78-107 amide) is secreted in man in response to physiological stimuli e.g. a mixed meal. Glucagon-like peptide-1, in concentrations corresponding to those observed in response to meals, strongly stimulates insulin secretion, in all mammals studied, even more potently than the gastric inhibitory peptide. Thus, glucagon-like peptide-1 fulfills the classic criteria for being a hormone and is likely to be a new incretin. The glucagon inhibitory effect of glucagonlike peptide-1 (PG 78-107 amide) probably further potentiates the effect of glucagon-like peptide- 1 on glucose metabolism and distinguished this peptide from other intestinal
\end{abstract}

peptides which have been proposed as incretins. Glucagonlike peptide- 1 also inhibits gastric acid secretion and gastric emptying in man. The latter delays nutrient entry to the intestine and thereby diminishes meal-induced glucose excursions. Elevated plasma concentrations of immunoreactive glucagon-like peptide- 1 have been reported in Type 2 (noninsulin-dependent) diabetic patients, however, the consequences of the elevation are not yet known. However, elevated levels of glucagon-like peptide-1 in patients with increased gastric emptying rate (post-gastrectomy syndromes) may be responsible for the exaggerated insulin secretion seen in these patients.

Key words: Glucagon-like peptide-1, proglucagon, incretin, insulin, glucagon, somatostatin.
All peptide hormones have been shown to derive from much larger percursor molecules, the "so called" prohormones. Thanks to gene technology the amino acid sequences of many of these prohormones are now known. Apart from the actual hormone sequences, many prohormones have been found to contain additional, up to now, totally unknown peptide sequences. As exemplified by pro-opiomelanocortin these additional peptides may have new interesting biological effects. One such prohormone is the prohormone glucagon, proglucagon.

The structure of anglerfish proglucagon (PG) was published by Lund et al. in 1982 [1]. Its structure was deduced from the nucleotide sequence of cDNA from anglerfish islets encoding the precursor of glucagon. Apart from the glucagon sequence the prohormone was shown to contain an $\mathrm{N}$-terminal amino acid sequence of 52 amino acids and a C-terminal 34 amino acid glucagon-like sequence [1]. The structure of the first mammalian PG deduced from the nucleotide sequence of glucagon-encoding mRNA from hamster pancreatic islets was published by Bell et al. in 1983 [2]. Apart from glucagon, proglucagon was shown to contain a 91-amino acid C-terminal sequence contain- ing two glucacon-like sequences, flanked by pairs of basic amino acids, known as potential cleavage sites. The peptides were named glucagon-like peptide-1 (GLP-1) and glucagon-like peptide-2 (GLP-2) [2]. The discovery of the two new glucagon-like sequences initiated a surge of studies. There were numerous questions to answer: were the glucagon-like peptides produced in the tissues, would these peptides be released by the producing cells and by which stimuli, and last, but not least, could any of these peptides have a biological function, and would this function then be glucagon-like? Many workers have contributed to the attempts to answer these questions from 1983 till today. Not all questions are yet answered but the progress made so far has important implications. It is now generally accepted that the naturally occurring GLP-1 (a peptide corresponding to PG 78-107 amide), secreted from the distal ileum, has unique effects on the endocrine pancreas and thereby potentially affects glucose metabolism. This GLP-1 molecule has been postulated to be a novel "incretin". Incretin is a term coined by Zunz and $\mathrm{La}$ Barre in 1929 for a humoral factor from the intestinal tract which releases insulin or potentiates the glucose-induced 
Preproglucagon

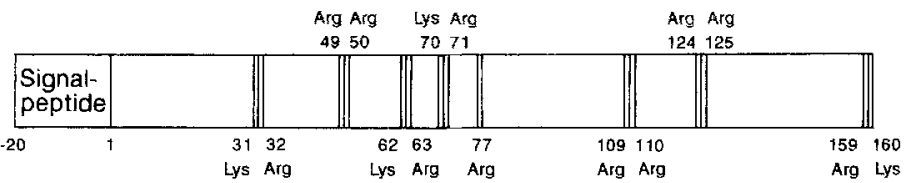

Proglucagon

\begin{tabular}{|c|c|c|c|c|}
\hline GRPP & GLUCAGON & GLP-1 & Sp-2 & GLP-2 \\
\hline
\end{tabular}

POSTTRANSLATIONAL PROCESSING
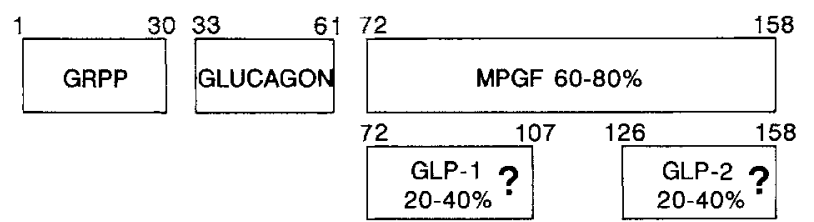

Small intestine
Fig. 1. Proglucagon processing in mammalian pancreas and small intestinal mucosa. The structure of the glucagon precursor is indicated diagrammatically at the top. Sequences of dibasic amino acids, potential post-translational cleavage sites, are indicated. The peptide products are shown in boxes, marked according to their position in the prohormone sequence in the upper corners of the boxes together with the name. The relative amount of a given peptide sequence occurring in each organ is indicated as per cent of the total amount of proglucagon processed. In the pancreas the main products are glucagon, the $\mathrm{N}$-terminal 30 amino acid peptide, which in the pig has been named glicentin-related pancreatic peptide (GRPP), and the major proglucagon fragment (MPGF). Smaller amounts of not fully characterized glucagon-like peptide- 1 and -2 (GLP-1 and GLP-2) immunoreactivities are also formed. In the small intestine the main products are glicentin, GLP-1 (PG 78-107 amide), GLP-2 and a small intervening peptide: spacer peptide-2 (Sp-2) insulin release [3]. The ability of an oral glucose load to release more insulin than an intravenous glucose infusion, despite a similar increase in the blood glucose level is due to the release of "incretin" [4]. The chemical structure of "incretin" has not yet been determined with certainty, but gastric inhibitory polypeptide, also called glucose-dependent insulin releasing polypeptide or GIP which is produced in the upper small intestine could serve as an incretin. However, it seems probable that several peptides acting together might account for the incretin effect. In fact, in 1981 Lauritzen et al. [5], who studied the incretin effect in patients with small intestinal resections, found that patients with residual ileal segments had greater incretin effects than patients with small jejunal remnants and no ileum, despite identical GIP levels in the two groups, and concluded from these findings that an unknown incretin factor must be present in the distal small intestine [5].

This review analyses the published literature on glucagon-like peptides in order to document these proposals and discusses the evidence that GLP-1 (PG 78-107 amide) is a true hormone.

Literature about glucagon biosynthesis published before the discovery of the full proglucagon structure is generally not covered by this review. The reader is referred to the complete literature review published in 1983 [6].

\section{The structure of preproglucagon}

Shortly after the publication of the mammalian proglucagon structure [2] Bell and co-workers described the human preproglucagon gene to be a 9.4 kilobase polynu- cleotide, presumably composed of six exons (540 base pairs) and five introns [7, 8]. Bell and co-workers [2] proposed that the amino acid sequence of the preprohormone, as deduced both from the hamster cDNA and from the human gene, is composed of a 20 amino acid signal peptide, followed by a 160 amino acid prohormone, proglucagon (PG 1-160). The amino acid sequences of bovine, rat, guinea pig and degu proglucagon were found to be very similar to hamster preproglucagon [9-12]. In the original report, Bell et al. missed the sixth exon of the human glucagon gene, whereby the C-terminal arg ( $\arg 160)$ could not be predicted to exist [7]. This was pointed out by Heinrich et al. in 1984 [10] and confirmed by White et al. in 1986 [8]. All known mammalian PGs contain, at the PG residues no.33-61, the sequence of glucagon (Fig. 1). As a consequence they all contain an N-terminal sequence, corresponding to PG 1-30. In contrast to the findings in anglerfish and chicken where one glucagon-like sequence is found C-terminally $[1,13]$, mammalian PG has a 91 amino acid sequence containing two glucagon-like amino acid sequences. Proteolytic processing of the C-terminal portion of $\mathrm{PG}$ at all pairs of basic amino acid residues, potential post-translational cleavage sites, would result in two peptides, each containing a glucagonlike sequence, and a short intervening peptide. Bell and co-workers in 1983 named these peptide sequences GLP1 (corresponding to PG 72-108), GLP-2 (corresponding to PG 126-158 or 126-160 if the two C-terminal basic amino acids were not removed) and spacer peptide-2 (corresponding to PG 111-122) [7] (Fig.1). The degree of sequence homology of $P G$ between species varies in the different $P G$ regions: the weakest homology is found in the region containing the $\mathrm{NH}_{2}$-terminal 30 amino acid fragment (e.g. $84 \%$ homology man/hamster). The homology 


$$
\begin{aligned}
& \text { His - Ala - Glu - Gly - Thr - Phe - Thr - Ser - Asp - Val - } \\
& \text { Ser - Ser - Tyr - Leu - Glu - Gly - Gln - Ala - Ala - Lys - } \\
& \text { Glu - Phe - Ile - Ala - Trp - Leu - Val - Lys - Gly - Arg - } \mathbf{N H}_{2} \text { - }
\end{aligned}
$$

Mammalian glucagon-like peptide-1 (PG 78-107 amide)

Fig.2. The amino acid structure of mammalian glucagon-like peptide-1 (PG 78-107 amide). Amino acids shown in italic letters occur at the same position in the sequence of glucagon

in the region containing the GLP-2 sequence is higher ( $91 \%$ homology man/hamster), but the highest homology is found in the two regions containing the glucagon sequence and the GLP-1 sequence (both 100\% homology man/hamster) [2,7]. Actually, the amino acid sequences of GLP-1 are identical in all mammals studied so far (Fig.2). This high degree of conservation would be consistent with similarly conserved biological functions.

Interestingly, anglerfish have been shown by Lund et al. [14] to have two glucagon genes encoding two different proglucagon molecules. Both of the anglerfish PG molecules contain one GLP-1 like sequence (both with an $\mathrm{N}$-terminal six amino acid deletion, compared with mammal GLP-1), but neither of the PG molecules contain a GLP-2 sequence. This finding might indicate that GLP-2 is a more recent addition in evolution. However, the occurrence of two glucagon genes in anglerfish could also represent a different mechanism for generating two GLP's such as in mammals [14].

The preproglucagon gene has been shown to be expressed both in the pancreas and the intestine [15]. By cloning and sequencing of cDNAs coding for preproglucagon from human pancreas and colon, combined with primer extension analysis of mRNA from pancreas, ileum and colon, Novak et al. [15] found that the mRNAs for preproglucagon are identical in the pancreas and in the gut. A similar conclusion was reached by Mojsov et al. [16] who studied hybridizing intestinal and pancreatic rat mRNAs by Northern blot analysis. This would be consistent with the predictions by Bell et al. [7] and White et al. [8] that there is only a single gene encoding glucagon in mammals.

However, long before the elucidation of the complete PG structure it had been shown by purification and sequence analysis of pancreatic and intestinal peptides that the peptides produced in the glucagon-cells in the pancreas and in the gut were different. The pancreatic Alpha cells produce glucagon and the 30 amino acid $\mathrm{N}$-terminal peptide (named glicentin-related pancreatic peptide, in the pig), while the L-cells in the small intestine produce glicentin (or "enteroglucagon", corresponding to PG 1-69) and oxyntomodulin (corresponding to PG 33-69) (Fig. 1) [17]. Since the glucagon-encoding mRNAs from pancreas and intestine are identical, the occurrence of different $\mathrm{N}$-terminal $\mathrm{PG}$ products in the two tissues can only be explained by tissue-specific, differential post-translational processing of the prohormone.
In some species glucagon-immunoreactive peptides have been identified in the stomach (dog) and in the brain (rat, dog and neonatal human). A cDNA encoding PG transcribed from the nucleotide sequence of human neonatal brainstem mRNA has been shown by Drucker et al. [18] to be identical to PG encoding cDNA from the pancreas and intestine. The sequence of preproglucagon encoding nucleotides in the dog stomach is not known, but it is believed that these products are also derived from the single glucagon gene.

\section{Nomenclature}

As discussed later, there is more than one naturally occurring GLP-1 immunoreactive molecule, and many synthetic GLP-1 analogues are now available. Their nomenclature is quite confusing, since the different workers use different names for the same molecular forms. To meet these inconsistencies it was decided in this review, to designate the peptides according to their position in the prohormone sequence (PG 1-160) together with the name, (eg. GLP-1 (PG 78-107 amide)).

GLP-1 (PG 78-107 amide) has the following synonyms: GLP-1 (7-36 amide), intestinal GLP-1, and truncated GLP-1 (TGLP-1). GLP-1 (PG 78-108) is synonymous with GLP-1 (7-37) and "insulinotropin". GLP-1 (PG 72-107 amide) is synonymous with GLP-1 (1-36 amide) or "full-length GLP-1". The presence or absence of C-terminal amidation of these moieties depends on whether it is believed that the PG sequence no. 108-110, gly-arg-arg, a potential amidation site, is substrate for an amidation reaction or not.

The large pancreatic GLP-1-containing molecule will, as first suggested by Patzelt and Schug [19], be designated the major proglucagon fragment (MPGF), as its exact sequence is not yet known.

\section{Molecular characterization of naturally occurring peptides containing the GLP-1 sequence (PG 78-107) (GLP-1 molecules)}

\section{Pancreatic GLP-1 molecules}

In 1979 Patzelt et al. [20] identified a 10,000 $\mathrm{M}_{\mathrm{r}}$ proglucagon fragment from rat pancreatic islets, which he named the major proglucagon fragment (MPGF). By comparing the amino acid composition of MPGF and the known structure of rat PG, Patzelt et al. [21] later deduced that rat MPGF probably corresponds to PG 72-158. Also GLP-1 molecules in pancreata from pig, dog and man have been studied by chromatography $[16,22-30]$. The available evidence suggests that the main GLP-1 moiety produced in the pancreas is indeed a large peptide, which contains both the GLP-1 and the GLP-2 sequences. The reported presence of smaller pancreatic GLP-1 molecules may result from enzymatic degradation of larger peptides prior to gel filtration or from inexpedient extraction procedures or specificities of the antisera used for the measurements $[16,22-33]$. 


\section{Enteric GLP-1 molecules}

Because the largest number of enteroglucagon producing cells had previously been found in the ileum and the colon $[34,35]$, these tissues were examined for GLP-1 molecules in rat [16, 23], pig [24], dog [25] and in man [26, 27, 29]. All workers found that the majority of the GLP-1 immunoreactivity eluted as a small molecule coeluting with either GLP-1 (PG 72-107 or -8) or GLP-1 (PG 78-107 or -8). By sequence analysis of purified peptide from human and porcine intestine, the peptide has been shown to correspond to PG 78-107 amide [36, 37]. Likewise, mass spectroscopy of purified rat GLP-1 was compatible with the theoretical mass of PG 78-107 amide [38]. In conclusion, it is apparent that both the $\mathrm{N}$-terminal and the $\mathrm{C}$-terminal parts of $P G$ are processed differentially in the pancreas and the small intestine.

\section{Gastric GLP-1 molecules}

By chromatographic analysis of extracts of canine gastric mucosa, known to produce glucagon $[39,40]$ almost all of the GLP-1 immunoreactivity eluted at a position corresponding to the MPGF.

\section{Cerebral GLP-1 molecules}

GLP-1 immunoreactivity has been found in whole brain extracts, and brain stem and hypothalamus extracts from rat and $\operatorname{dog}[18,25,41-43]$. By chromatographical analysis the immunoreactivity eluted corresponding to either GLP-1 (PG 72-107 amide) or (PG 78-107 amide). The significance of the presence of GLP-1 in the brain is not known.

\section{Cellular localization of GLP-1 molecules}

\section{Pancreas}

In mammals GLP-1 immunostaining is found in the islets of Langerhans, co-localized with glucagon and GLP-2 immunostaining [16, 24, 27, 29, 44, 45]. By electron microscopy the different products of $\mathrm{PG}$ have been shown to be packaged in separate compartments of the secretory granules in the pancreatic Alpha-cells: GLP-1, GLP-2 and glucagon immunostaining in the electron dense core, and immunostaining for the 30 amino acid $\mathrm{N}$-terminal product of $\mathrm{PG}$ in the less electron dense halo $[16,46,47]$. A totally different peptide, pancreastatin, (an amidated fragment of chromogranin A) has also been found in the Alpha cells, packaged in the less electron dense halo of the secretory granules [48]. The significance of the differential packaging of the PG products in the secretory granules and the coexistence with pancreastatin is unknown.

\section{Gastrointestinal tract}

In the gastrointestinal tract GLP-1 and GLP-2 immunostaining co-localized with glicentin/enteroglucagon immunostaining has been shown in open-type endocrine cells in ileal mucosa in all mammals studied so far $[16,24$, 27, 44], including human colonic [46] and rectal mucosa [45]. Peptide YY (PYY) immunostaining has been shown to be co-localized with glicentin immunostaining (and therefore probably also with GLP-1 immunostaining) in all parts of the intestine [49-51]. The significance of the coexistence of PYY and the PG products is unknown.

\section{Stomach}

In tissue sections of dog gastric mucosa, known to harbour glucagon-producing cells [40], GLP-1 immunostaining has been shown to be co-localized with glucagon immunostaining [44].

\section{Brain}

The finding of cells in the nucleus tractus solitarius in rat brainstem which hybridize with a GLP-1 oligonucleotide probe suggests that there is a de novo synthesis of $P G$ in these cells [52]. Likewise, GLP-1 immunostaining co-localized with glucagon and glicentin immunostaining has been shown in cells of the nucleus of the solitary tract in rat brainstem [53], in the primate, Tupaia Berlangeri [45] and in man. The reported occurrence of GLP-1 immunostaining cells in rat hypothalamus is more doubtful $[18,53,54]$.

\section{Secretion of GLP-1 molecules}

Secretion of GLP-1 molecules and stimuli for the secretion of GLP-1 molecules have been studied in isolated perfused organs from pig, rat and dog, and in vivo in man.

\section{Pancreatic secretion of GLP-1 molecules}

The amino acid, arginine, has been shown to stimulate the secretion of GLP-1 immunoreactivity from rat islets [19, $21]$, isolated perfused rat pancreas $[22,55]$ and isolated perfused pig pancreas [24]. The secreted GLP-1 immunoreactivity was characterized chromatographically and found to correspond to a large molecule, probably the MPGF, by some workers [21, 24], though Shima et al. [55] reported that most of the GLP-1 immunoreactivity coeluted with GLP-1 (PG 72-107 amide).

\section{Intestinal secretion of GLP-1 molecules}

The secretion of GLP-1 immunoreactivity has been shown to be stimulated by intraluminal glucose in isolated perfused pig ileum [24], and isolated perfused dog ileum $[56,57]$ and by the neuropeptide gastrin releasing peptide in isolated perfused pig ileum [24]. By chromatographic analysis the secreted GLP-1 immunoreactivity was reported by all workers to correspond to a relatively small molecule coeluting either with GLP-1 (PG 72-107 amide) [24] or GLP-1 (PG 78-107 amide) [56].

Shima et al. [58] investigated the relationship between the molecular structures of sugars and their ability to 
stimulate the release of immunoreactive GLP-1 from ileal loops in anaesthetized dogs. They reported that D-glucose, D-galactose, D-glucuronic acid, 3-O-methyl-D-glucose, maltose, sucrose and maltitol stimulated the release of GLP-1 immunoreactivity while D-fructose, D-fucose, D-xylose, D-mannose and, surprisingly, lactose did not. The common chemical features of those sugars that stimulated GLP-1 secretion were reported to be an electron density near C (6), an equatorial hydroxyl group at C (2), and an axial hydroxyl group at C (1). In conclusion, GLP-1 immunoreactive material is released both from the pancreas and from the small intestine in response to physiological stimuli also known to cause the release of glucagon/glicentin. From the pancreas a large GLP-1 immunoreactive molecule probably corresponding to the MPGF is secreted, whereas the small intestine mainly secretes a smaller molecule, corresponding to GLP-1 (PG 78-107 amide) or GLP-1 (PG 72-107 amide). The present knowledge, that the extractable intestinal GLP-1 in man, rat and pig is GLP-1 (PG 78-107 amide), makes it very likely that the GLP-1 immunoreactive moiety secreted from the intestine is also GLP-1 (PG 78-107 amide).

\section{Circulating GLP-1 molecules in normal man}

The secretion of GLP-1 molecules in man has been studied through measurements of peripheral venous plasma. Most workers have found that accurate measurements of GLP-1 in plasma require previous extraction of plasma to remove unspecific protein interference in the radioimmunoassay $[30,59]$. Unspecific interference by plasma proteins, which is also a problem in many other radioimmunoassays, has been studied in detail by several groups (see [60] and [61] for glucagon and gastrin radioimmunoassays).

Some disagreement prevails as to which GLP-1 molecules predominate in fasting plasma. Some workers have found that in the fasting state the predominating GLP-1 molecule in plasma behaves chromatographically like MPGF $[27,62,63]$, while other workers reported that the predominating molecule corresponds to GLP-1 (PG 72107 amide) $[28,30]$. The disagreement could be due to the different chromatographic techniques employed. Thus, some workers have reported that for example Seppak used in many studies retains the MPGF $[28,62]$.

Both Kreymann et al. [30] und Ørskov et al. [27, 59, 62] found that the concentration of GLP-1 immunoreactivity in plasma rose in response to a mixed meal. By chromatographic analysis of postprandial plasma Ørskov et al. [27] found that the majority of the GLP-1 immunoreactivity eluted at the position of synthetic GLP-1 (PG 72-107 amide) or GLP-1 (PG 78-107 amide), which could not be separated by this gel filtration procedure.

Intravenous arginine, an established stimulus for the pancreatic glucagon-secreting cells, has been shown by several workers to stimulate GLP-1 secretion in man [30, 62]. By chromatographic analysis of plasma this GLP-1 immunoreactivity was shown to correspond to a large peptide, probably the MPGF.
Oral glucose, a known stimulus for the glicentin/GLP-1 producing cells in the intestinal mucosa, was also shown to stimulate GLP-1 immunoreactivity in peripheral plasma $[32,62]$. By chromatographic analysis it was shown that this GLP-1 immunoreactivity in plasma corresponded to GLP-1 (PG 78-107 amide).

In conclusion, the predominating GLP-1 in plasma after a mixed meal and after oral glucose coelutes with GLP-1 (PG 78-107 amide), reflecting a stimulation of the gut. After intravenous arginine the main GLP-1 molecule in plasma is the MPGF, reflecting a stimulation of the endocrine pancreas.

\section{Circulating GLP-1 molecules in disease}

Circulating GLP-1 molecules in disease have so far only been studied in a few conditions, namely in Type 2 (noninsulin-dependent) diabetic patients, in gastrectomized patients, in uraemic patients and in patients with the glucagonoma syndrome.

\section{GLP-1 molecules in Type 2 diabetes}

GLP-1 immunoreactivity in plasma in the fasting state, following oral glucose and intravenous arginine has been shown to be significantly higher in Type 2 diabetic patients than in matched control subjects $[62,63]$. By chromatographic analysis of plasma from the Type 2 diabetic patients it was shown that the predominating GLP-1 molecule both in the fasting state and after intravenous arginine was a large molecule, corresponding to the MPGF, whereas after oral glucose the predominating GLP-1 molecule in plasma coeluted with synthetic GLP-1 (PG 78-107 amide) [62, 63].

\section{GLP-1 molecules in gastrectomized subjects}

Miholic et al. [30] studied the effects of a meal and Kreymann et al. [64] studied the effects of oral glucose on GLP1 secretion in gastrectomized subjects after meal/glucose stimulation. In both studies a significantly higher GLP-1 concentration was measured in the gastrectomized subjects than in the control subjects. By chromatographic analysis both groups found that this GLP-1 immunoreactivity corresponded to GLP-1 (PG 78-107 amide). It was speculated by Miholic et al. [64] that the elevated GLP-1 concentrations might account for the exaggerated insulin secretion seen in these patients in response to a meal, which sometimes results in reactive hypoglycaemia.

\section{GLP-1 molecules in uraemic subjects}

GLP-1 immunoreactivity in fasting plasma from uraemic patients has been shown to be significantly higher than in control subjects [65]. By chromatographic analysis the GLP-1 immunoreactivity eluted in two equally large peaks corresponding to the MPGF and a moiety co-elut- 
Table 1. Elimination of exogenous glucagon-like peptide (GLP) (PG 72-107 amide) and GLP 1 (PG 78-107 amide)

\begin{tabular}{|c|c|c|c|c|c|}
\hline Species & Peptide & $\begin{array}{l}\mathrm{T} 1 / 2 \\
(\mathrm{~min})\end{array}$ & $\begin{array}{l}\mathrm{MCR} \\
\left(\mathrm{ml} \cdot \mathrm{kg}^{-1} \cdot \mathrm{min}^{-1}\right)\end{array}$ & Authors & Comments \\
\hline$\overline{\text { Rat }}$ & GLP & $8.2 \pm 0.4$ & Not determined & Ruiz-Grande et al. [66] & Single bolus injections \\
\hline Man & GLP & $17 \pm 2$ & $2.2 \pm 0.3$ & Scholdager et al. [68] & Continuous infusion \\
\hline Rat & GLP 1 & $4.5 \pm 0.2$ & Not determined & Ruiz-Grande et al. [69] & Single bolus injection \\
\hline Man & GLP 1 & $11 \pm 2$ & $13 \pm 3$ & Scholdager [68] & Infused continuously \\
\hline
\end{tabular}

$\mathrm{T} 1 / 2$, plasma half-life; $\mathrm{MCR}$, metabolic clearance rate

ing with GLP-1 (PG 72-107 amide). This finding suggests that the kidneys play a role in the removal of these PG products from plasma.

\section{GLP-1 molecules in patients with glucagon-producing tumours}

Uttenthal et al. [29] and George et al. [26] studied GLP-1 molecules in tumour tissue and plasma from patients with glucagon producing tumours. The concentration of GLP-1 immunoreactivity was elevated in plasma samples and in all extracts of tumour tissue. By chromatographic analysis of both plasma and extracted tissue the size of GLP-1 molecules varied from patient to patient.

\section{Metabolism of GLP-1 molecules}

The plasma half-lives and metabolic clearance rates of both exogenous GLP-1 (PG 72-107 amide) and GLP-1 (PG 78-107 amide) have been studied by several workers $[30,66-69]$. The results of the studies in rat and man are shown in Table 1. In comparison the metabolic clearance rate of glucacon is $9-12 \mathrm{ml} \cdot \mathrm{kg}^{-1} \cdot \mathrm{min}^{-1}$ and the half-life is 5-6 min. Thus, the half-life of GLP-1 is only slightly longer than that of glucagon.

\section{Biological effects of GLP-1 molecules}

The biological effects of GLP-1 molecules have been studied in isolated organs from rat and pig and in vivo in man.

\section{Biological effect of major proglucagon fragment (MPGF)}

No studies on the effect of MPGF have been published. The exact structure is not known, and hence a synthetic replica of the peptide is not available for biological studies.

\section{Biological effect of GLP-1 (PG 72-107 amide)}

Synthetic GLP-1 (PG 72-107 amide) in very high concentrations (above $1 \mathrm{nmol} / \mathrm{l}$ ) was found to stimulate insulin secretion from isolated rat pancreatic islets [70] and from isolated perfused rat pancreas [71], whereas synthetic GLP-1 (PG 72-107 amide) in isolated perfused pig pancreas, in concentrations up to $10^{-9} \mathrm{~mol} / \mathrm{l}$, neither affected the exocrine secretion, nor the secretion of insulin, glucagon, somatostatin or GLP-2 from the endocrine pancreas [24].

GLP-1 (PG 72-107 amide) in very high concentrations $\left(10^{-8}\right.$ to $\left.10^{-6} \mathrm{~mol} / \mathrm{l}\right)$ was reported to stimulate glycerol release from isolated rat adipocytes, but much less potently than glucagon [72].

Intravenous infusion of synthetic GLP-1 (PG 72-107 amide) in doses resulting in supraphysiological peripheral concentrations of GLP-1 (500 pmol/l) in healthy subjects slightly inhibited pentagastrin-induced acid secretion [68].

A few studies have been published describing binding sites for GLP-1 in the rat brain. Shimizu et al. [42] reported specific binding of GLP-1 (PG 72-107 amide) to homogenates of rat pituitary glands and thalamus/hypothalamus and Hoosein and Gurd [73] found that GLP-1 (PG 72-107 amide) at $10^{-9} \mathrm{~mol} / \mathrm{l}$ increased the cAMP formation two-fold in membrane preparations of rat hypothalamus and pituitary.

Both Ghiglione et al. [74] and Shimizu et al. [75] reported that GLP-1 (PG 72-107 amide) did not, like glucagon, bind to rat hepatocyte membranes, and did not stimulate the production of cAMP in isolated rat hepatocytes. Likewise, Ørskov et al. [unpublished results] found that GLP-1 (PG 72-107 amide) did not have specific binding sites on porcine hepatocyte membranes.

In conclusion, GLP-1 (PG 72-107 amide) in physiological concentrations has no known biological effect. Supraphysiological concentrations of GLP-1 may affect insulin secretion, lipid metabolism and acid secretion, but all of these effects may be due to degradation of the peptide to GLP-1 (PG 78-107 amide). The significance of the putative receptors on brain membranes is not known.

\section{Biological effects of GLP-1 (PG 78-107 amide/108)}

a) Effects on the endocrine pancreas. GLP-1 (PG 78-107 amide) was first shown in 1987 [36] to stimulate insulin secretion in the isolated perfused porcine pancreas. Later GLP-1 was shown to have a similar effect in isolated perfused dog pancreas [76] and rat pancreas [71, 76-79], 
mouse pancreas [80] and in concious sheep [81]. The nonamidated peptide GLP-1 (PG 78-108) has also been shown to stimulate insulin secretion in perfused rat pancreas [82-85] and in concious rats [84]. The insulin stimulatory effect of both GLP-1 (PG 78-107 amide) and GLP1 (PG 78-108) has been shown to be glucose-dependent $[71,79,82]$. Both Shima et al. [71] and Suzuki et al. [86] compared the effects of GLP-1 (PG 78-107 amide) and gastric inhibitory peptide, GIP, an incretin candidate from the upper small intestine, on insulin secretion in the isolated perfused rat pancreas. While Shima et al. [71] reported that GLP-1 was much more potent than GIP, Suzuki et al. [86] claimed that the two peptides (both infused at $10^{-9} \mathrm{~mol} / \mathrm{l}$ ) were equipotent.

The insulin stimulatory effect of GLP-1 (PG 78-107 amide) has also been studied in man. Kreymann et al. [30] found by intravenous infusion of GLP-1 together with glucose that insulin secretion was stimulated greatly and $\mathrm{Na}-$ than [87] found that infusion of GLP-1 increased insulin secretion two-fold in healthy volunteers. The effects of GLP-1 (PG 78-107 amide) and GIP on insulin secretion in healthy volunteers have been studied by several workers [30, 88-90]. In all studies both GIP and GLP-1 stimulated insulin secretion, but GLP-1 was more potent than GIP, and GLP-1, in contrast to GIP, had insulinotropic actions at euglycaemia [30, 88]. Furthermore, Nauck et al. [89] showed that the insulin response in normal subjects after an infusion of GLP-1 and GIP in physiological concentrations together with intravenous glucose, corresponded to the insulin response to a matched oral glucose load. Thus, by addition of these peptides to the intravenous glucose the incretin effect was mimicked. Interestingly, the incretin effect, as well as the secretion of GIP and GLP-1 after an oral glucose load, have been shown to be preserved in diabetic patients after pancreas transplantation, in spite of the denervation of the pancreas and the systemic insulin delivery [91]. Gutniak et al. [92] studied the effect of GLP-1 on isoglycaemic meal-related insulin requirement in Type 2 and Type 1 (insulin-dependent) diabetic patients. They found that the insulin requirements after GLP-1 infusion in both the Type 2 and the Type 1 diabetic patients were greatly reduced and speculated that GLP-1 might be a new treatment for diabetes [92].

Thus, GLP-1 is, also in man, the most potent endogenous insulin-stimulating peptide isolated to date, considerably more potent than GIP. In physiological concentrations GLP-1 is more potent at hyperglycaemia and euglycaemia than at hypoglycaemia. The glucose-dependency of the effect of GLP-1 (PG 78-107 amide) is similar to that of GIP.

GLP-1 (PG 78-107 amide) was also found to stimulate somatostatin secretion in a perfused pig pancreas [93] and dog pancreas [76], and in a rat pancreatic islet cell culture [94].

Finally, GLP-1 (PG 87-107 amide) in physiological concentrations has been shown to inhibit glucagon secretion from isolated perfused pancreas in the pig [93], in the $\operatorname{dog}[76]$ and in the rat $[76,77,79]$. The inhibitory effect was reported to be more marked at low than at high glucose levels [76, 79, 93]. Interestingly, GLP-1 (PG 78-107 amide) did not affect glucagon secretion in a rat pancre- atic cell culture [94]. This finding might indicate that the effect of GLP-1 (78-107 amide) on insulin and somatostatin secretion is direct, while the effect on glucagon secretion may be indirect (a paracrine effect mediated via somatostatin?) and therefore may require intact pancreatic islets.

The non-amidated GLP-1 (PG 78-108) has been shown by Weir et al. [83] not to inhibit glucagon secretion.

In man, Kreymann et al. [30] found that GLP-1 (PG 78107 amide) infused intravenously into healthy volunteers together with glucose significantly inhibited glucagon secretion.

b) Effects on the stomach. The effect of GLP-1 (PG 78107 amide) on the stomach has been studied because of the known inhibitory effect of glucagon on gastric acid secretion [95]. While GLP-1 was shown to neither affect somatostatin secretion nor gastrin secretion in the pig stomach [93], the peptide was found to stimulate somatostatin release and inhibit gastrin release in a perfused rat stomach $[96,97]$. These latter effects were not abolished by tetrodotoxin, indicating that the effects were not neurally mediated [96]. Schmidtler et al. [98] have reported a direct stimulatory effect of GLP-1 on dispersed rat parietal cells.

Reports on the occurrence of GLP-1 receptors in the stomach are contradictory: strong specific binding has been reported $[99,100]$ as well as weak binding $[101]$ and no specific binding [102].

In man, GLP-1 in physiological concentrations has been shown to inhibit gastric acid secretion $[68,103,104]$ and to decrease gastric emptying [104]. It is not known if the inhibitory effect of GLP-1 on acid secretion in man is direct or indirect. The inhibitory effect of glucagon is presumably indirect [105].

c) Possible effects on other tissues. GLP-1 receptors or effects have been looked for in several tissues. Oben et al. [106] recently reported that GLP-1 stimulates fatty acid synthesis in explants of rat adipose tissue. Kanse et al. [101] found high levels of GLP-1 binding to homogenates of rat brain stem and lung, whereas low binding to homogenates of pancreas, liver, adipose tissue, stomach mucosa and spleen was found. Specific binding of GLP-1 to a $66,000 \mathrm{M}_{\mathrm{r}}$ single ligand binding protein isolated from cell membranes of rat lung was reported by Richter et al. [107, 108]. The size of this putative GLP-1 receptor was comparable with the reported size of the GLP-1 receptor on rat insulinoma cells.

Seifert et al. [111] reported specific binding of GLP-1 to homogenates of the superior colliculus, the pretectal area, the nucleus of the solitary tract and the hypothalamus in rats. The significance of the reported GLP-1 binding to rat lung, brain and adipose tissue is not known.

\section{Biological effect of GLP-1 analogues (Table 2)}

Suzuki et al. [77] compared the effects of the GLP-1 analogues, PG 72-107 amide, PG 78-107 amide, PG 77-107 amide, and PG 79-107 amide, on an isolated perfused rat 
Table 2. Known biological effects of glucagon-like peptide-1 (GLP-1) molecules in physiological concentrations

GLP-1 (PG 78-107 amide/108)
Stimulates insulin secretion (man rat, pig)
Stimulates somatostatin secretion from pancreas (pig, dog, rat)
Inhibits glucagon secretion (man, pig, dog, rat)
Stimulates somatostatin secretion from (rat) stomach
Inhibits gastric acid secretion (man)
GLP-1 (PG $72-107$ amide/108)
No known effects
Major proglucagon fragment (PG 72-158?)
No known effects

The species in which the investigations were carried out are indicated in parentheses

pancreas. GLP-1 (PG 78-107 amide) (and very high concentrations of GLP-1 (PG 72-107 amide)) stimulated insulin secretion, while the analogues PG 77-107 amide and PG 79-107 amide did not. Only GLP-1 (PG 78-107 amide) inhibited glucagon secretion in the perfused pancreas [77]. In a study by Gefel et al. [84] the insulin stimulatory effect of GLP-1 (PG 78-107 amide) was found to be similar to that of GLP-1 analogue PG 78-108 in the isolated rat pancreas, while the GLP-1 analogue PG 78-105 was less potent, and PG 78-104 and PG 79-108 did not affect insulin secretion at all. Kawai et al. [112] found that GLP-1 (PG 78-107 amide) stimulates insulin secretion more potently in concious dogs than PG 78-108 and PG 78-106. Gallwitz et al. [113] compared the ability of GLP-1 (PG 78-107 amide) and two fragments corresponding to PG 78-97 and PG 93-107 amide to stimulate cAMP in rat insulinoma cells and found that only GLP-1 (PG 78-107 amide) was able to stimulate cAMP. Yanaihara et al. [97] compared the somatostatin releasing effects of the GLP-1 analogues: GLP-1 (PG 72-108), (PG 78-108), (PG 78107), (PG 78-106) and (PG 78-104) in an isolated perfused rat stomach. At $10^{-8} \mathrm{~mol} / \mathrm{l}$ the GLP-1 analogues, PG 78108, PG 78-107, PG 78-106 and PG 78-104, all stimulated somatostatin secretion significantly, while GLP-1 (PG 72108) did not stimulate somatostatin.

The results of these studies indicate that an intact $\mathrm{N}$-terminus of GLP-1 (PG 78-107 amide) is very important for the effects on insulin and somatostatin secretion, while an intact C-terminus seems to be important for the effect on insulin secretion.

\section{GLP-1 molecules and GLP-1 receptors in transformed cells}

Almost all studies of effects of GLP-1 molecules on transformed cells have been performed in different strains of a rat insulinoma cell line (RIN) originally derived from a radiation-induced insulin-producing rat tumour $[114$, 115].

Philippe et al. [116] studied PG processing in a cloned rat insulinoma cell line, RIN 56A. By Northern blot analysis this cell line was found to express high levels of glucagon mRNA, and by chromatographical analysis to pro- duce small amounts of a GLP-1 immunoreactive moiety coeluting with synthetic GLP-1 (PG 72-108). Larger molecular weight moieties were not identified. Specific receptors for GLP-1 (PG 78-107 amide) [109, 117] and GLP-1 (PG 78-108) [118, 119] on RIN cells, not displacable by glucagon, GLP-2, GIP or any other member of the glucagon/secretin family have been described by several groups $[109,116-120]$. Binding of GLP-1 (PG 78-107 amide) and GLP-1 (PG 78-108) has been shown to be associated with increase in cyclic AMP concentration in the cell medium (in RIN m5F, RIN 1046-38 and RIN 1027 B2) $[109,119]$ and it was shown that guanine nucleotides significantly decreased receptor affinity to GLP-1 [118]. Furthermore, GLP-1 binding to RIN cells was shown to affect neither the membrane potential nor to change the intracellular levels of calcium [118]. It was concluded that the effect of GLP-1 (PG 78-107 amide) on RIN cells seems to be mediated solely by G-protein binding receptors associated with adenylate cyclase [118]. By covalent cross-linking of ${ }^{125}$ I-labelled GLP-1 to RIN $5 \mathrm{mF}$ cell membranes Göke et al. demonstrated a single, ligand-binding protein of a molecular weight of 63,000 , thought to be a GLP-1 receptor [121]. In a hamster islet cell line, InR1G9, Drucker et al. [122] found by gel filtration of extracted cells, that all GLP-1 immunoreactivity eluted at the position of synthetic GLP-1 (PG 72-108) and that phorbol myristate acetate stimulated the release of this GLP-1 immunoreactive moiety, suggesting that protein kinase $\mathrm{Cac}-$ tivating mechanisms were involved.

\section{References}

1. Lund PK, Goodman RH, Dee PC, Habener JF (1982) Pancreatic preproglucagon cDNA contains two glucagon-related coding sequences arranged in tandem. Proc Natl Acad Sci 79: 345349

2. Bell GI, Santerre RF, Mullenbach GT (1983) Hamster preproglucagon contaíns the sequence of glucagon and two related peptides. Nature 302: 716-718

3. Zunz E, La Barre J (1929) Contributions à l'étude des variations physiologiques de la sécrétion interne du pancreas: relation entre les sécrétions externe et interne du pancreas. Arch Internat Physiol Biochim 31: 20

4. McIntyre N, Holdsworth CD, Turner DS (1964) New interpretation of oral glucose tolerance. Lancet II: $20-21$

5. Lauritsen KB, Moody AJ, Christensen KC, Jensen SL (1981) Gastric inhibitory polypeptide (GIP) and insulin release after small-bowel resection in man. Scand J Gastroenterol 16: 417 423

6. Lefebvre PJ (1983) Glucagon. In: Lefebvre PJ (ed) Handbook of experimental pharmacology, Vol 1, 2. Springer, Heidelberg Berlin New York

7. Bell GI, Sanchez-Pescador R, Laybourn PJ, Najarian RC (1983) Exon duplication and divergence in the human preproglucagon gene. Nature 304: 368-371

8. White JW, Saunders GF (1986) Structure of the human glucagon gene. Nucleic Acids Research 14: 4683-4690

9. Lopez LC, Frazier ML, Su CJ, Kumar A, Saunders GF (1983) Mammalian pancreatic preproglucagon contains three glucagon-related peptides. Proc Natl Acad Sci 80: 5485-5489

10. Heinrich G, Gros P, Habener JF (1984) Glucagon gene sequence-four of six exons encode separate functional domains of rat pre-proglucagon. J Biol Chem 259: 14082-14087

11. Seino S, Welsh M, Bell GI, Chan SJ, Steiner DF (1986) Mutations in the guinea pig preproglucagon gene are restricted to a 
specific portion of the prohormone sequence. FEBS lett 203: 25-30

12. Nishi M, Steiner DF (1990) Cloning of complementary DNAs encoding islet amyloid polypeptide, insulin and glucagon precursors from a new world rodent, the degu, octodon degus, Molecular Endocrinol 4: 1192-1198

13. Hasegawa S, Terazono K, Nata K, Takada T, Yamamoto H, Okamoto H (1990) Nucleotide sequence determination of chicken glucagon precursor cDNA. Chicken preproglucagon does not contain glucagon-like peptide II. FEBS lett 264:117-120

14. Lund PK, Goodman RH, Montminy MR, Dee PC, Habener JF (1982) Anglerfish islet pre-proglucagon II. J Biol Chem 158: 3280-3284

15. Novak U, Wilks A, Buell G, McEwen S (1987) Identical mRNA for preproglucagon in pancreas and gut. Eur $\mathbf{J}$ Biochem 164: 553-558

16. Mojsov S, Heinrich G, Wilson IB, Ravazzola M, Orci L, Habener JF (1986) Preproglucagon gene expression in pancreas and intestine diversifies at the level of post-translational processing. J Biol Chem 261: 11880-11889

17. Holst JJ (1983) Gut glucagon, enteroglucagon, gut glucagonlike immunoreactivity, glicentin-current status. Gastroenterol 84: $1602-1613$

18. Drucker DJ, Asa S (1988) Glucagon gene expression in vertebrate brain. J Biol Chem 263: 13475-13478

19. Patzelt C, Schug G (1981) The major proglucagon fragment: an abundant islet protein and secretory product. FEBS lett 129 : $127-130$

20. Patzelt C, Tager HS, Carroll RJ, Steiner DF (1979) Identification and processing of proglucagon in pancreatic islets. Nature 282: 260-266

21. Patzelt C, Schiltz E (1984) Conversion of proglucagon in pancreatic alpha cells: the major endproducts are glucagon and a single peptide, the major proglucagon fragment, that contains two glucagon-like sequences. Proc Natl Acad Sci 81: 5007-5011

22. Manaka H, Tanigushi H, Wada K et al. (1987) Glucagon-like peptide-1 in the rat pancreas. Biomedical Res 8: 1-11

23. Mojsov S, Kopczynski MG, Habener JF (1990) Both amidated and nonamidated forms of glucagon-like peptide I are synthesized in the rat intestine and the pancreas. J Biol Chem 265: $8001-8008$

24. Ørskov C, Holst JJ Knuhtsen S, Baldissera FGA, Poulsen SS, Nielsen OV (1986) Glucagon-like peptides GLP-1 and GLP-2, predicted products of the glucagon gene, are secreted separately from pig small intestine but not pancreas. Endocrinol 119: $1467-1475$

25. Suda K, Takahashi H, Fukase N, Manaka H, Tominaga M, Sasaki H (1989) Distribution and molecular forms of glucagon-like peptide in the dog. Life Sciences 45: 1793-1798

26. George SK, Uttenthal LO, Ghiglione M, Bloom SR (1985) Molecular forms of glucagon-like peptides in man. FEBS lett 192: 275-278

27. Ørskov C, Holst JJ, Poulsen SS, Kirkegaard P (1987) Pancreatic and intestinal processing of proglucagon in man. Diabetologia 30: $874-881$

28. Hirota M, Shimizu I, Ohboshi C, Nishino T, Shima K (1987) A large molecular form of glucagon-like peptide-1 (GLP-1) immunoreactivity is co-released with glucagon from pancreas by arginine in normal subjects. Clin Chim Acta 167: 293-297

29. Uttenthal LO, Ghiglione M, George SK, Bishop AE, Polak JM, Bloom SR (1985) Molecular forms of glucagon-like peptide-1 in human pancreas and glucagonomas. J Clin Endocrinol Metab $61: 472-479$

30. Kreymann B, Ghatei MA, Williams G, Bloom SR (1987) Glucagon-like peptide-1 7-36: a physiological incretin in man. Lancet II: 1300-1303

31. Newgard CB, Holst JJ (1981) Heterogeneity of somatostatin like immunoreactivity in extracts of porcine, canine and human pancreas. Acta Endocrinol 98: 564-572

32. Kenny AJ (1955) Extractable glucagon of the human pancreas. J Clin Endocrinol Metab 15: 1089-1092
33. Patzelt C, Weber B (1986) Early O-glycosidic glycosylation of proglucagon in pancreatic islets: an unusual type of prohormonal modification. EMBO J 5: 2103-2108

34. Bryant MC, Bloom SR (1975) Characterization of the new gastrointestinal hormones. Gut 16: $840-848$

35. Larsson LI, Holst JJ, Håkanson R, Sundler F (1975) Distribution and properties of glucagon-immunoreactivity in the digestive tract of various mammals: an immunohistochemical and immunocytochemical study. Histochemistry 44: 281-287

36. Holst JI, Ørskov C, Nielsen OV, Schwartz TW (1987) Truncated glucagon-like peptide-I, an insulin-releasing hormone from the distal gut. FEBS lett 211:169-174

37. Ørskov C, Bersani M, Johnsen AH, Højrup P, Holst JJ (1989) Complete sequences of glucagon-like peptide- 1 from human and pig small intestine. $\mathrm{J}$ Biol Chem 264: 12826-12829

38. Kreymann B, Yiangou Y, Kanse S, Williams G, Ghatei MA, Bloom SR (1989) Isolation and characterisation of GLP-1 7-36 amide from rat intestine. FEBS lett 242: 167-170

39. Holst JJ (1978) Extrapancreatic glucagons. Digestion 17: 168190

40. Morita S, Doe K, Yip CC, Vranic M (1976) Measurement and partial characterization of immunoreactive glucagon in gastrointestinal tissues in dogs. Diabetes 25: 1018-1023

41. Yoshimoto S, Hirota M, Ohboshi C, Shima K (1989) Identification of glucagon-like peptide-1 (7-36) amide in rat brain. Annals of Clinical Biochemistry 26: 169-171

42. Shimizu I, Hirota M, Ohboshi C, Shima K (1987) Identification and localization of glucagon-like peptide- 1 and its receptor in rat brain. Endocrinol 121: 1076-1082

43. Kreymann B, Ghatei MA, Burnet P et al. (1989) Characterization of glucagon-like peptide-1-(7-36) amide in the hypothalamus. Brain Res 502: 325--331

44. Vaillant CR, Lund PK (1986) Distribution of glucagon-like peptide- $\mathrm{I}$ in canine and feline pancreas and gastrointestinal tract. $\mathbf{J}$ Histochem Cytochem 34: 1117-1124

45. Kauth T, Metz J (1987) Immunohistochemical localization of glucagon-like peptide-1. Use of poly- and monoclonal antibodies. Histochemistry 86: 509-515

46. Varndell IM, Bishop A, Sikri E, Uttenthal LO, Bloom SR, Polak JM (1985) Localization of glucagon-like peptide (GLP) immunoreactants in human gut and pancreas using light and electron microscopic immunocytochemistry. J Histochem Cytochem 33: 1080-1086

47. Ravazzola M, Orci L (1980) Glucagon and glicentin IR are topologically segregated in the alfa granule of the human pancreatic A-cell. Nature 284: 66-71

48. Lamberts R, Schmidt WE, Creutzfeldt W (1990) Light and electron microscopical immunocytochemical localization of pancreastatin-like immunoreactivity in porcine tissues. Histochemistry 93: 369-380

49. Böttcher G, Sjölund K, Ekblad E, Håkanson R, Schwartz TW, Sundler F (1984) Coexistence of peptide YY and glicentin immunoreactivity in the endocrine cells of the gut. Regul Pept 8 : 261-266

50. Ali-Rashedi A, Varndell IM, Adrian TE et al. (1984) Peptide YY (PYY) immunoreactivity is co-stored with glucagon-related immunoreactants in endocrine cells of the gut and pancreas. Histochemistry 80: 487-491

51. Böttcher G, Aluments J, Håkanson R, Sundler F (1986) Co-existence of glicentin and peptide $Y Y$ in colorectal L-cells in cat and man. An electron microscopic study. Regul Pept 13: 283291

52. Han VKM, Hynes MA, Jin C, Towle AC, Lauder JM, Lund PK (1986) Cellular localization of proglucagon/glucagon-like peptide I messenger RNAs in rat brain. J Neurosci Res 16: 97-107

53. Jin SL, Han VKM, Simmons JG et al. (1988) Distribution of glucagon like peptide I (GLP-I), glucagon, and glicentin in the rat brain: an immunocytochemical study. J Comp Neurol 271:519532

54. Salazar I, Vaillant C (1990) Glucagon-like immunoreactivity in hypothalamic neurons of the rat. Cell Tiss Res 261:355-358 
55. Shima K, Hirota M, Ohboshi C, Sato M, Nishino T (1987) Release of glucagon-like peptide 1 immunoreactivity from the perfused rat pancreas. Acta Endocrinol 114: 531-536

56. Manaka H, Sugiyama K, Takahashi H, Fukase N, Sasaki H (1990) tGLP-1 release from the isolated perfused canine ileum. Digestion 46 [Suppl 1]: 66 (Abstract)

57. Namba M, Itoh H, Watanabe $\mathrm{N}$ et al. (1990) Multiple forms of glucagon-like peptide-1 and glucagon-like immunoreactivities in canine gastrointestinal tract and their release into circulation. Biomed Res 11:247-254

58. Shima K, Suda T, Nishimoto K, Yoshimoto S (1990) Relationship between molecular struetures of sugars and their ability to stimulate the release of glucagon-like peptide-1 (GLP-1) from canine ileal loops. Acta Endocrinol (Copenh) 123: 464-470

59. Ørskov C, Holst JJ (1987) Radioimmunoassays for glucagonlike peptides-1 and -2 (GLP-1 and GLP-2). SICLI 47: 165-174

60. von Schenck H, Grubb AO (1982) Interference of immunoglobulins in two glucagon radioimmunoassays. Clin Chem 28: $1103-1108$

61. Rehfeld JF, Schwartz TW, Stadil F (1977) Immunochemical studies on macromolecular gastrins. Gastroenterol 73: 469-473

62. Ørskov C, Jeppesen J, Madsbad S, Holst JJ (1990) Proglucagon products in plasma on non-insulin dependent diabetics and non-diabetic controls in the fasting state and following oral glucose and intravenous arginine. J Clin Invest 87: 415-423

63. Hirota M, Hashimoto M, Hiratsuka M et al. (1990) Alterations of plasma immunoreactive glucagon-like peptide-1 behavior in non-insulin-dependent diabetics. Diab Res Clin Pr 9: 179-185

64. Miholic J, Ørskov C, Holst JJ, Kotzerke J (1991) Postprandial glucagon-like peptide-1 (GLP-1), enteroglucagon and emptying of the gastric substitute after total gastrectomy. Dig Dis Sci 36: $1361-1370$

65. Ørskov C, Andreasen J, Holst JJ (1991) All products of proglucagon are elevated in plasma from uremic patients. J Clin Endocrinol Metab 74: 379-384

66. Ruiz-Grande C, Pintado J, Lopez-Novoa JM, Valverde I (1987) Removal of ${ }^{125}$ I glucagon-like peptides (GLP-1 and GLP-2) from rat plasma; role of the kidney. Diabetologia 30: 576A (Abstract)

67. Oshima I, Hirota M, Ohboshi C, Shima K (1988) Comparison of half-disappearance times, distribution volumes and metabolic clearance rates of exogenous glucagon-like peptide 1 and glucagon in rats. Regul Pept 21: 85-89

68. Schjoldager BTG, Mortensen PE, Christiansen J, Ørskov C, Holst JJ (1989) GLP-1 (Glucagon-like Peptide 1) and truncated GLP-1, fragments of human proglucagon, inhibit gastric acid secretion in man. Dig Dis Sci 35: 703-708

69. Ruiz-Grande C, Alarcon C, Valverde I (1990) Renal catabolism of glucagon-like peptide-1 (7-36) amide. Diabetologia 33: A218 (Abstract)

70. Schmidt WE, Siegel EG, Creutzfeldt W (1985) Glucagon-like peptide-1 but not glucagon-like peptide-2 stimulates insulin release from isolated rat pancreatic islets. Diabetologia 28: 704707

71. Shima K, Hirota M, Ohboshi C (1988) Effect of glucagon-like peptide-1 on insulin secretion. Regul Pept 22:245-252

72. Ruiz-Grande C, Casla A, Rovira A, Valverde I (1988) Glucagon-like peptides and lipolysis in isolated rat adipocytes. Diabetologia 31: 538A (Abstract)

73. Hoosein NM, Gurd RS (1984) Human glucagon-like peptides 1 and 2 activate rat brain adenylate cyclase. FEBS lett 178: 83-86

74. Ghiglione M, Blazquez E, Uttenthal LO et al. (1985) Glucagonlike peptide-1 does not have a role in hepatic carbohydrate metabolism. Diabetologia 28: 920-922

75. Shimizu I, Hirota M, Ohboshi C, Shima K (1986) Effect of glucagon-like peptide-1 and -2 on glycogenolysis in cultured rat hepatocytes. Biomed Res 7: 431-437

76. Kawai K, Suzuki S, Ohashi S et al. (1989) Comparison of the effects of glucagon-like peptide-1-(1-37) and -(7-37) and glucagon on islet hormone release from isolated perfused canine and rat pancreases. Endocrinol 124: 1768-1773
77. Suzuki S, Kawai K, Ohashi S, Mukai H, Yamashita K (1989) Comparison of the effects of various $\mathrm{C}$-terminal and $\mathrm{N}$-terminal fragment peptides of glucagon-like peptide- 1 on insulin and glucagon release from the isolated perfused rat pancreas. Endocrinol 125: 3109-3114

78. Fehmann HC, Göke B, Göke R, Trautmann ME, Arnold R (1989) Synergistic stimulatory effect of glucagon-like peptide-1 (7-36) amide and glucose-dependent insulin-releasing polypeptide on the endocrine rat pancreas. FEBS lett 252: 109-112

79. Komatsu R, Matsuyama T, Namba M et al. (1989) Glucagonostatic and insulinotropic action of glucagonlike peptide I(7-36)-amide. Diabetes 38:902-905

80. Fridolf T, Böttcher G, Sundler F, Ahren B (1991) GLP-1 and GLP-1 7-36 amide: influences on basal and stimulated insulin and glucagon secretion in the mouse. Pancreas 6:208-215

81. Faulkner A, Pollock HT (1991) Effects of truncated glucagonlike peptide-1 on the responses of starved sheep to glucose. J Endocrinol 129: 55-58

82. Mojsov S, Weir GC, Habener JF (1987) Insulinotropin: Glucagon-like peptide-I (7-37) co-encoded in the glucagon gene is a potent stimulator of insulin release in the perfused rat pancreas. J Clin Invest 79:616-619

83. Weir GC, Mojsov S, Hendrick GK, Habener JF (1989) Glucagonlike peptide I (7-37) actions on endocrine pancreas. Diabetes 38: 338-342

84. Gefel D, Hendrick GK, Mojsov S, Habener JF, Weir GC (1990) Glucagon-like peptide -I analogs: effects on insulin secretion and adenosine $3^{\prime} 5^{\prime}$-monophosphate formation. Endocrinol 126: 2164-2168

85. Hendrick G, Wong K, Lundquist P, Nakashima P, Buckley D (1990) Glucagon-like peptide I-(7-37) (GLP) enhances glucose disposal in vivo. Diabetes 39: [Suppl 1] 260A (Abstract)

86. Suzuki S, Kawai K, Ohashi S, Mukai H, Murayama Y, Yamashita K (1990) Reduced insulinotropic effects of glucagonlike peptide I-(7-36)-amide and gastric inhibitory polypeptide in isolated perfused diabetic rat pancreas. Diabetes 39: 13201325

87. Nathan DM, Fogel H, Mojsov S, Habener JF (1990) Insulinotropic action of glucagon-like peptide-I, 7-37 (GLP-I(7-37)) in non-diabetic and NIDDM subjects. Diabetes 39: [Suppl 1] 142A (Abstract)

88. Andersen DK, Meneilly GS, Sclater A et al. (1990) The insulinotropic effect of GIP: A dose response comparison and comparison to glucagon-like peptide-1(7-37) amide (GLP). Diabetes 39: [Suppl 1] 142A (Abstract)

89. Nauck M, Bartels E, Ørskov C, Ebert R, Creutzfeldt W (1991) Insulinotropic effect of a combination of human synthetic GIP and GLP-1 (7-36 amide) at physiological plasma glucose in man. Diabetologia 34 (Suppl 2) A14 (Abstract)

90. Kreymann B, Ghatei MA, Schusdziarra V, Bloom SR, Classen M (1990) Does the incretin effect exist for GIP or GLP-1 7-36 amide at physiological glucose concentrations in man? Digestion 46: [Suppl 1] 59 (Abstract)

91. Nauck M, Büsing M, Siegel EG et al. (1990) Preserved incretin effect after heterotopic pancreas transplantation in type 1diabetic patients. Diabetologia 33: A38 (Abstract)

92. Gutniak M, Ahren B, Efendic S (1990) Glucagon-like insulinotropic peptide-1 (7-36)- new approach to treating diabetes? Diabetologia 33: A73 (Abstract)

93. Ørskov C, Holst JJ, Nielsen OV (1988) Effect of truncated glucagon-like peptide-1 (proglucagon-(78-107) amide) on endocrine secretion from pig pancreas, antrum, and non-antral stomach. Endocrinol 123: 2009-2013

94. d'Alessio DA, Fujimoto WY, Ensinck JW (1989) Effects of glucagonlike peptide I-(7-36) on release of insulin, glucagon, and somatostatin by rat pancreatic islet cell monolayer cultures. Diabetes 38: 1534-1538

95. Loud FB, Frogerg D, Reichardt J, Holst JJ, Rehfeld JF, Christiansen J (1978) Inhibition of meal stimulated gastric acid secretion in man by exogenous and endogenous pancreatic glucagon. Scand J Gastroenterol 13: 795-798 
96. Eissele R, Koop H, Arnold R (1990) Effect of glucagon-like peptide-1 on gastric somatostatin and gastrin secretion in the rat. Scand J Gastroenterol 25: 449-454

97. Yanaihara N, Mochizuki T, Hoshino M et al. (1990) Somatostatinotropic effect of GLP-I-related peptides. Digestion 46: [Suppl 1] 124 (Abstract)

98. Schmidtler J, Schepp W, Janczewska I (1991) GLP-1 (7-36) amide,-(1-37) and -(1-36) amide: potent cAMP dependent stimuli of rat parietal cell function. Am J Physiol 260: G940G950

99. Uttenthal LO, Blazquez E (1990) Characterization of high-affinity receptors for truncated glucagon-like peptide-1 in rat gastric glands. FEBS lett 262: 139-141

100. Hansen AB, Gespach CP, Rosselin GE, Holst JJ (1988) Effect of truncated glucagon-like peptide-1 on cAMP in rat gastric glands and HGT-1 human gastric cancer cells. FEBS lett 236: $119-122$

101. Kanse SM, Kreymann B, Ghatei MA, Bloom SR (1988) Identification and characterization of glucagon-like peptide-1 7-36 amide-binding sites in the rat brain and lung. FEBS lett 241: 209-212

102. Ørskov C, Poulsen SS (1991) Autoradiography of rat tissues with GLP-1. Diabetes 40: 1292-1296

103. O'Halloran DJ, Nikou GC, Kreymann B, Ghatei MA, Bloom SR (1990) Glucagon-like peptide-1 (7-36)-NH2: a physiological inhibitor of gastric acid secretion in man. J Endocrinol 126: 169 173

104. Wettergren A, Scholdager B, Mortensen PE, Myhre J, Christiansen J, Holst JJ (1990) Truncated GLP-1 (proglucagon 87107 amide) from distal gut: role in regulation of gastric and pancreatic functions. Digestion 46 [Suppl 1]: 120 (Abstract)

105. Loud FB, Holst JJ, Christiansen J, Rehfeld JF (1988) Effect of glucagon on vagally induced gastric acid secretion in humans. Dig Dis Sci 33: 405-408

106. Oben J, Morgan L, Fletcher J, Marks V (1991) Effect of the entero-pancreatic hormones, gastric inhibitory polypeptide, glucagon-like polypeptide-1 (7-36) amide, on fatty acid synthesis in explants of rat adipose tissue. J Endocrinol 130: 267-272

107. Richter G, Göke R, Göke B, Arnold R (1990) Characterization of receptors for glucagon-like peptide-1 (7-36) amide on rat lung membranes. FEBS lett 267: 78

108. Richter G, Göke R, Göke B, Schmidt H, Arnold R (1991) Characterization of glucagon-like peptide I (7-36) amide receptors on rat lung membranes by covalent cross-linking. FEBS lett 280: $247-250$

109. Göke R, Conlon JM (1988) Receptors for glucagon-like peptide-1 (7-36) amide on rat insulinoma-derived cells. J Endocrinol 116: $357-362$

110. Blackmore PF, Mojsov S, Exton JH, Habener JF (1991) Absence of insulinotropic glucagon-like peptide-I (7-37) receptors on isolated rat liver hepatocytes. FEBS lett 283: 7-10
111. Seifert H, Gallwitz B, Schmidt WE, Creutzfeldt W (1990) Mapping of ${ }^{125}$ I-GLP-1(7-36)-NH2 binding sites in rat brain. Digestion 46: [Suppl 1] 104 (Abstract)

112. Kawai K, Suzuki S, Ohashi S, Mukai H, Murayama Y, Yamashita K (1990) Effects of truncated glucagon-like peptide-1 on pancreatic hormone release in normal concious dogs. Acta Endocrinol 123: 661-667

113. Gallwitz B, Schmidt WE, Conlon JM, Creutzfeldt W (1990) Glucagon-like peptide-1 (7-36) amide: characterization of the domain responsible for binding to its receptor on rat insulinoma RINm5F cells. J Molecul Endocrinol 5: 33-39

114. Bhathena SJ, Oie HK, Gazdar AF, Voyles NR, Wilkins SD, Recant L (1982) Insulin, glucagon and somatostatin receptors on cultured cells and clones from rat islet cell tumor. Diabetes 31 : 521-531

115. Chick WL, Appel MC, Weir GCet al. (1980) Serially transplantable chemically induced rat islet cell tumor. Endocrinol 107: 954-960

116. Philippe J, Mojsov S, Drucker D, Habener JF (1986) Proglucagon processing in a rat islet cell line resembles phenotype of intestine rather than pancreas. Endocrinol 119:2833-2839

117. Ørskov C, Nielsen JH (1988) Truncated glucagon-like peptide 1 (proglucagon 78-107 amide) an intestinal insulin-releasing peptide, has specific receptors on rat insulinoma cells (RIN SAH). FEBS lett 229: 175-178

118. Fehmann HC, Habener JF (1991) Functional receptors for the insulinotropic hormone glucagon-like peptide I (7-37) on a somatostatin secreting cell line. FEBS lett 279:335-340

119. Drucker DJ, Philippe J, Mojsov S, Chick W, Habener JF (1987) Glucagon-like peptide-I stimulates insulin gene expression and increases cyclic AMP levels in rat islet cell line. Proc Natl Acad Sci 84:3434-3438

120. Göke R, Trautmann E, Haus E et al. (1989) Signal transmission after GLP-1 (7-36) amide binding in RINm5F cells. Am J Physiol 257: G397-G401

121. Göke R, Cole T, Conlon JM (1989) Characterization of the receptor for glucagon-like peptide-1 (7-36) amide on plasma membranes from rat insulinoma-derived cells by covalent cross-linking. J Mol Endocrinol 2: 93-98

122. Drucker DJ, Philippe J, Mojsov S (1988) Proglucagon gene expression and posttranslational processing in a hamster islet cell line. Endocrinol 123: 1861-1867

\author{
Dr. C. Ørskov \\ Department of Clinical Chemistry KK 3011 \\ Rigshospitalet \\ Blegdamsvej 9 \\ DK-2100 Copenhagen \\ Denmark
}

